UDK 613.955, 956

\title{
SANITARY AND EPIDEMIOLOGICAL SAFETY AND RISK TO HEALTH OF CHILDREN AND TEENAGERS DURING EDUCATION
}

\section{V.R. Kuchma', E.I. Shubochkina', S.G. Safonkina, V.V. Molgavanov' ${ }^{3}$ E.M. Ibragimova ${ }^{3}$}

\author{
${ }^{1} \mathrm{FSBI}$ Scientific Center of Children Health Under the Russian Academy of Medical Sciences, \\ 2/62, Lomonosovsky, Moscow, 119991, Russia, \\ ${ }^{2}$ Research institute of hygiene and health care of children and adolescents, \\ Scientific Center of Children's Health, RAMS, \\ building 5, Maly Kazenny lane, Moscow, 105064, Russia, \\ ${ }^{3} \mathrm{FBH}$ "Center of Hygiene and Epidemiology in Moscow", \\ $4 / 9,129626$, Russia
}

\begin{abstract}
The materials on the dynamics of sanitary and epidemiological safety of educational institutions of Moscow and the state of health of children and teenagers for the period 2005-2010 have been assessed. The increased risks of growth of outbreaks of infectious diseases and the school-connected disorders of health of children and teenagers have been proved at the actual deterioration of conditions of training in educational institutions of the 2nd group of sanitary condition. It is shown that the assessment criteria of sanitary and epidemiological safety of educational institutions need new approach for a more objective assessment of educational establishments to reduce the risks to pupils' health. The onclusions have been drawn that the control system of sanitary and epidemiologic safety of pupils in the conditions of modern activity regulations of services and establishments of Russian Agency for Health and Consumer Rights has to include both the actions provided by the legislation and innovative actions - successfully approved in other fields of activity: production control over observance of health regulations and performance of sanitary and epidemiologic (preventive) actions depending on the level of their sanitary and epidemiologic safety, sanitary and epidemiologic audit in educational institutions.

Key words: sanitary and epidemiological safety of pupils, risks of emergence of outbreaks of infectious diseases and the school-connected disorders of health, system of management of sanitary and epidemiologic safety in educational establishments, innovative approaches.
\end{abstract}

Russia still shows negative health trends in children, and the reasons for that are living conditions of children and teenagers [1]. The biggest social load on children and teenagers is the education process. The impact of the learning environment at pre-schools and elementary schools (EF) where the students spend a bulk of their ime during the early years of life can lead to the so-called 'school' diseases as well as to deterioration of health. The main criterion to assess the sanitary and hygienic environment at educational facilities is the sanitary group (1st,

(C) Kuchma V.R., Shubochkina E.I., Safonkina S.G., Molgavanov V.V., Ibragimova E.M., 2014

Kuchma Vladislav Remirovich - corresponding member of the Russian Academy of Sciences, MD, Professor, Deputy Director of FSBI Scientific Center of Children Health under the Russian Academy of Medical Sciences, Director of the Research Institute of Hygiene and Health of Children and Adolescents (e-mail: vrkuchma@mtu-net.ru, kuchma@niigd.ru, tel.: +7-495-917-48-31).

Shubochkina Evgenia Ivanovna - MD, Head of the Laboratory of Hygiene of Vocational Training, Vocational Guidance and Labor of the Research Institute of Hygiene and Health of Children and Adolescents (e-mail: adlabhyg@yandex.ru, tel.: +7-495-917-46-39).

Ibragimova Evgenia Mikhailovna - senior research associate of the Laboratory of Hygiene of Vocational Training, Vocational Guidance and Labor of the Research Institute of Hygiene and Health of Children and Adolescents, CM (e-mail: adlabhyg@yandex.ru, tel.: +7-495-917-46-39).

Safonkina Svetlana Germanovna - CM, Deputy Chief Physician of the Federal Budget Healthcare Institution "Center of Hygiene and Epidemiology in Moscow" (e-mail: safonkina@mail.ru, tel.: +7-499-616-41-01).

Moldovanov Vladimir Valeryevich - CM, Head of Department of Hygiene of Children and Adolescents of the Federal Budget Healthcare Institution “Center of Hygiene and Epidemiology in Moscow” (e-mail: mvv7373@mail.ru, tel.: +7-495-64-59). 
2nd and 3rd) that they fall under; the positive dynamics in those groups often does not correspond with the negative trends in children's health condition $[3,4,10]$.

Accurate assessment of the sanitary and hygienic situation at the educational facilities to identify the main risk factors and prove their impact on student health should be an essential part of an action program in such situation [7]. However, health indicators as a component of the sanitary and hygienic assessment of the epidemiological situation are rarely use in the hygiene of children and teenagers.

The purpose of the research was to study the relationship between children's health in Moscow and the sanitary indicators of the environment at the educational institutions based on the official health data provided by Rospotrebnadzor.

Materials and methods. The study used the templates of the State and industrial statistical monitoring by the Moscow Rospotrebnadzor for 2005-2010 and the official statistics on morbidity preventative medical exam (PME) among children and teenagers for the same period. To assess the statistical accuracy of the results, we used Statistica 7.0 and evidence-based healthcare methods with health risk calculations based on the following contingency tables: AR, OR, RR $[7,8]$.

Results and the discussion. The average data on the breakdown of all the Moscow educational facilities into sanitary groups in 2005-2010 showed that the number of EFs in the 1 st group - the group that completely meets the sanitary requirements - had increased from $43,9 \%$ in 2005 to $52,3 \%(\mathrm{p}<0,001)$ in 2010 . Despite the positive dynamics, almost half of the educational institutions do not meet the current sanitary and epidemiological requirements and hygienic standards thus falling into the 2nd sanitary group. None of the educational institutions (boarding school, correctional institution, professional and industrial training centers) improved from the 1st sanitary group over the analyzed period. The level of sanitary and hygienic wellbeing (SHW) in the sanitary groups of the educational institutions is an integral indicator which includes a number of parameters that describe the study environment based on a visual inspection and the results of sanitary and hygienic tests. At the same time, the dynamics of individual important parameters of the study environment can be mitigated. The results of visual inspections for 2007-2010 showed an increase in the violations of the school and pre-school hygienic standards at the educational facilities: increased number of violations of the sanitary rules that regulate the room area per child (from 9,6 to $20,2 \%, p<0,001$ ), limit the places occupied (in class) at schools and pre-school institutions (from 13,1 to 19,0\%, p < 0,001), increased number of violations of the sanitary environment at the facilities (from 8,1 to $12 \%, p$ $<0,05)$, violations of the natural and artificial lighting requirements especially at schools of all 
types, including pre-school kindergarten (from 18,5 to $27,2 \%, p<0,01$ ). The figure below shows the dynamics of individual sanitary and hygienic violations based on the visual monitoring results for a 4-year period by type of educational institutions.

The figure calls attention to a sharp growth in the violations of such significant indicators at pre-school facilities as area per child, actual classroom occupancy and the organization of the educational process. Major risk factors at schools include violations of requirements to the choice of classrooms, sanitary environment in classrooms and, particularly, lighting requirements.

$\%$ violations

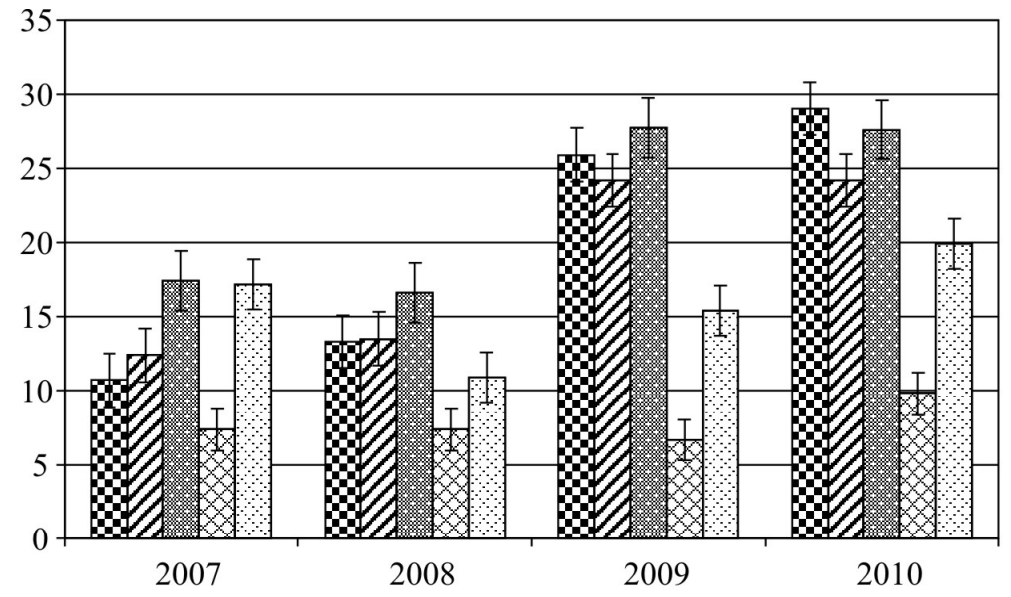

a

$\%$ violations

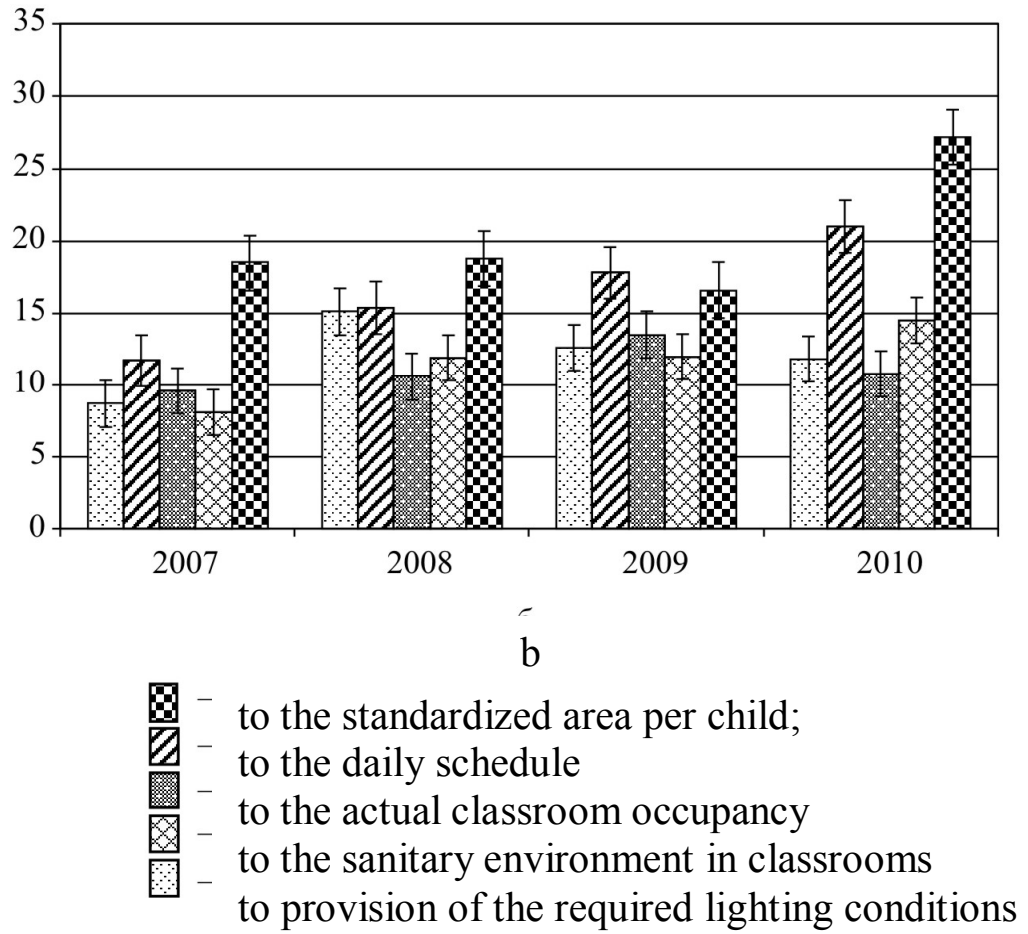

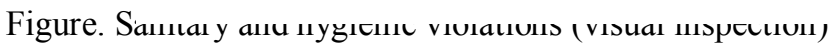
in Moscow in 2007-2010: a - pre-schools; b - schools 
In the same period, disease incidence in children aged 0-14, went up. The following health complaints became more frequent: related to the respiratory system including acute respiratory diseases (increased by 15,6\%), nervous system (by 18,9\%) and the digestive system (by 15,6\%), myopia (by 7,5) which may be associated with the above classroom factors.

However the worsening of the results of the indoor environment assessment at the educational institutions based on a visual inspection suggests consistent risk to children's health and does not allow decreasing the level of the sanitary group of the educational facility without proving the data by laboratory testing [6]. According to the data, the number of Rospotrebnadzor programs and activities aimed at the educational facilities including laboratory testing has significantly decreased [6]. As a result, underassessed actual worsening in the environmental conditions at the educational institutions of group 2 given the current assessment criteria may result to higher potential health risks for children and teenagers especially when it comes to important hygienic parameters that reflect the conditions at the educational institutions.

Underassessment of such health risks is confirmed by the results of the analysis of infection outbreaks at the educational institutions of various levels of the sanitary and hygienic environment (Table 1).

The assessment of the frequency of infection outbreaks registered at the educational institutions in 7 Moscow districts (2 793 schools) in 2010 showed that the absolute risk (AR) of infection outbreaks is significantly higher $(t=6,9, p \leq 0,001)$ at the educational facilities with worsened environment, i.e. the 2nd sanitary group, as compared to the 1st group. Particular attention should be paid to the assessment of the infection outburst AT at the facilities in the 3rd group where this indicator is considered to be a critical one: $\mathrm{AR}=4,3 \pm 3,0 \%, 95 \%$ th confidence interval (from $-1,58$ to $+10,18$ ), i.e. the confidence interval has a higher dispersion with negative values which implies its random nature in the event of low data count.

Based on the contingency table, we calculated the odds ratio (OR) of the infection outburst and the relative ratio (RR) of their occurrence at the educational facilities of the 1 st and 2nd groups.

The chance of infection outburst at the facilities of the 2nd sanitary group were by more than 3 times higher $(\mathrm{OR}=3,12 \pm 0,497)$, as compared to the 1 st group. The relative risk $(\mathrm{RR})$ that reflects the relationship among the factors (in this case - poor educational environment) and the outburst capacity totaled 2,91 $\pm 0,17$, the etiological fraction (proportional added risk due to the quality of the environment - sanitary groups) was high - $\mathrm{EF}=65,6 \%$.

Consequently, the obtained data strongly demonstrates that the relative risk of infection outbursts increases considerable with poor educational environment, in particular, at the 
violations of the sanitary requirements to the classroom environment at the educational facilities of the 2nd group.

To assess the relationship between the level of sanitary and hygienic environment at the educational institutions with other health indicators, we selected 3 Moscow districts with various sanitary conditions at the main educational facilities (pre-schools and schools).Here we calculated the percentage of children that deal with poor educationa environment (Table 2).

Table 1

Disease cases at Moscow educational institutions in $\mathbf{2 0 1 0}$ with the account for the sanitary and hygienic level of the indoor quality

\begin{tabular}{|c|c|c|c|c|c|c|}
\hline \multirow{2}{*}{ Indicator } & \multicolumn{2}{|c|}{ 1st sanitary group } & \multicolumn{2}{c|}{ 2nd sanitary group } & \multicolumn{2}{c|}{ 3rd sanitary group } \\
\cline { 2 - 7 } & $\begin{array}{c}\text { Number of } \\
\text { educational } \\
\text { institutions }\end{array}$ & $\begin{array}{c}\text { Number of } \\
\text { outbursts }\end{array}$ & $\begin{array}{c}\text { Number of } \\
\text { educational } \\
\text { institutions }\end{array}$ & $\begin{array}{c}\text { Number of } \\
\text { outbursts }\end{array}$ & $\begin{array}{c}\text { Number of } \\
\text { educational } \\
\text { institutions }\end{array}$ & $\begin{array}{c}\text { Number of } \\
\text { outbursts }\end{array}$ \\
\hline Distribution by groups & 1243 & 42 & 1504 & 148 & 46 & 2 \\
\hline $\begin{array}{c}\text { Absolute risk of outburst } \\
\text { occurance, \% }\end{array}$ & & $3,4 \pm 0,5$ & & $9,8 \pm 0,77$ & & $4,3 \pm 3,0$ \\
\hline $95 \%$ confidence level & \multicolumn{3}{|c|}{$t=6,9 p \leq 0,001(2-1)$} & $8,3-11,3$ & & $-1,58-10,18$ \\
\hline Significance of differences & \multicolumn{3}{|c|}{$1,92-4,84$} & & & \\
\hline
\end{tabular}

Table 2

\section{Dynaics in the number of children in 2007-2010 studying in various sanitary and hygienic conditions in the three Moscow districts}

\begin{tabular}{|c|c|c|c|c|c|c|c|}
\hline \multirow{3}{*}{$\begin{array}{c}\text { Monitoring, } \\
\text { year }\end{array}$} & \multicolumn{7}{|c|}{ Indicator } \\
\hline & \multirow{2}{*}{$\begin{array}{c}\text { Total number } \\
\text { of children }\end{array}$} & \multicolumn{2}{|c|}{ 1st sanitary group } & \multicolumn{2}{|c|}{ 2nd sanitary group } & \multicolumn{2}{|c|}{ 3rd sanitary group } \\
\hline & & абс. & $\%$ & абс. & $\%$ & абс. & $\%$ \\
\hline \multicolumn{8}{|c|}{ Central District } \\
\hline 2010 & 75497 & $51957^{*}$ & 68,8 & $23393^{*}$ & 31,0 & 147 & 0,2 \\
\hline 2009 & 76721 & $51278^{*}$ & 66,8 & $25229 *$ & 32,0 & 2,214 & 2,8 \\
\hline 2008 & 75541 & $47111^{*}$ & 62,4 & $28040^{*}$ & 37,6 & & \\
\hline 2007 & 76079 & 48917 & 64,3 & 27162 & 35,7 & & \\
\hline \multicolumn{8}{|c|}{ Northern District } \\
\hline 2010 & 99051 & $54063^{*}$ & 54,6 & $43454^{*}$ & 43,95 & 2534 & 2,6 \\
\hline 2009 & 97093 & $48197^{*}$ & 49,7 & $46019^{*}$ & 47,4 & 2,807 & 2,9 \\
\hline 2008 & 99445 & $48879^{*}$ & 49,15 & $47570^{*}$ & 47,84 & 2,996 & 3,05 \\
\hline 2007 & 113268 & 46066 & 40,7 & 63773 & 56,3 & 3,429 & 3,0 \\
\hline \multicolumn{8}{|c|}{ Southern District } \\
\hline 2010 & 150319 & $36979 *$ & 24,6 & 111215 & 74,0 & 2,125 & 1,4 \\
\hline 2009 & 146157 & $36889^{*}$ & 25,2 & 107090 & 73,3 & $2,178^{*}$ & 1,5 \\
\hline 2008 & 144461 & 33 937* & 23,5 & 107976 & 74,7 & $2,548^{*}$ & 1,8 \\
\hline 2007 & 144887 & 32804 & 22,6 & 109144 & 75,3 & 2,939 & 2,0 \\
\hline
\end{tabular}

Note : * accuracy $p \leq 0,001$ (dynamics over a 4-year period).

Central Administrative District (CAD) turned out to be conventionally 'disease-free'; here, two-thirds of children (from $64,3 \%$ to $68,8 \%$ ) studied at the educational institutions of the 1st sanitary group in 2007-2010, from 37,6 to 31,0\% - at the educational institutions of the 2nd sanitary group. Over that period, the number of children studying in poor indoor environment i.e. 
at the institutions of the 2nd sanitary group - went down $(\mathrm{p}<0,001)$, and the number of children studying in the environment that meets the sanitary standards went up.

In the Northern Administrative District (NAD) from 40,7\% to 54,6\% of children studied at the educational instituions of the 1 st sanitary group, and from $44,0 \%$ to $56,3 \%$ of children studied at the institutions of the2nd sanitary group with 'satisfactory' indoor classroom environment. Over the 4 years of the monitoring, the number of children studying in poor indoor environment went down significantly $(\mathrm{p}<0,001)$, and the number of children studying in the favorable indoor environment went up. However almost half of the children continued studying in the conditions that did not meet the sanitary requirements. Moreover, from 3,0\% to 2,6\% of children were studying at the facilities of the 3rd sanitary group which have poor indoor classroom environment with exceeded maximum permissible chemical concentrations and exceeded maximum allowable chemical concentrations by the laboratory results and instrumental research results - as well as had infection outbursts. The 3rd sanitary group included pre-schools and secondary schools. The number of children in the group decreased significantly only in 2010 .

Southern Administrative District (SAD) was considered 'unfavorable' in terms of the sanitary situation; only $22,6-25,2 \%$ of children studied in the favorable indoor conditions. The bulk of children (up to 75\%) studied in poor indoor conditions typical of the 2nd sanitary group, and from 2,0 to $1,4 \%$ studied at the facilities of the 3rd group. Positive trends in the number of children studying at the educational institutions of the 1st sanitary group though statistically significant did not considerably influence the number of children studying at the institutions with poor indoor environment.

We processed the results of medical examinations including the data on the number of exained school-age children (7-17) with a distribution by health groups (Table 3) as well as of individual health disorders identified at pre-school medical exams and graduation medical exams.

A comparative analysis of the data on the number of children of various health groups is not sufficient for a precise assessment of the impact of the classroom conditions on children's health. For example, the number of healthy children residing in a 'disease-free' district (1st sanitary group) as compared to the other two groups was significantly higher; the number of children in the 2 nd health group with functional disorders was lower. Still the number of children with chronic diseases was higher in the CAD as compared with the other two districts, except for the 5th sanitary group which was bigger in the SAD as compared to the CAD. 
Insufficient information value of the analyzed indicators may be associated with the fact that the statistical report forms contain averaged data (for all the age groups of the examined children aged 7[17) based on the medical examination results and lack such in regards to the stages of the school-pre-school period which could have provided a more objective overview of the change in health when studying in different conditions.

Such dynamic indicators are provided for individual functional disorders - poor vision, postural disorder - which may be determined by the school indoor conditions. Additionally, we calculated the risks of vision deterioration and postural disorders in children using the odds ratio $(\mathrm{OR})$ and the data from the three districts taking into account significant differences in the sanitary well-being of the educational institutions. The risk of vision disorder in children from before entering a pre-school till high school gradiation turned out to be rather higher in the districts with poor sanitary and epidemiological conditions.

The differences were significant for the CAD-NAD $(t=3,8, p \leq 0,001)$ and, respectively, for the CAD-SAD $(t=3,3, p \leq 0,001)$. The risks of postural disorders for the pre-school-school period also had significant and accurate differences as compared to the 'disease-free' district and the two other districts: CAD-NAD $(\mathrm{t}=4,1, \mathrm{p} \leq 0,001)$; CAD-SAD $(\mathrm{t}=4,4, \mathrm{p} \leq 0,001)$. No significant differences between the two Moscow districts with poor classroom conditions at the educations facilities (CAD and SAD) were obtained though the risk of postural disorders was higher in Moscow's SAD.

Conclusions. Violation of the sanitary requirements aimed at providing standard indoor environmental conditions at the educational institutions, based on a visual inspection, is followed by the worsening of the learning environment and the growth of infection outburst risks at the educational institutions of the 2 nd sanitary group which includes half of the city's educational institutions, and in some cases - up to $60-70 \%$. The criterial indicator to determine the 3rd sanitary group - inflectional outbursts - is not used widely among the specialists. 


\section{Student distribution by health groups based on preventative medical exams in 2010: in Moscow's CAD, NAD, SAD}

\begin{tabular}{|c|c|c|c|c|c|c|}
\hline $\begin{array}{l}\text { District in } \\
\text { Moscow }\end{array}$ & $\begin{array}{l}\text { Nunber of } \\
\text { examined } \\
\text { students }\end{array}$ & $\begin{array}{c}\text { 1st group, } \\
\%\end{array}$ & $\begin{array}{c}\text { 2nd group, } \\
\% \%\end{array}$ & $\begin{array}{c}\text { 3rd group, } \\
\%\end{array}$ & $\begin{array}{c}\text { 4th group, } \\
\%\end{array}$ & $\begin{array}{c}\text { 5th group, } \\
\% \%\end{array}$ \\
\hline & & 28,5 & 51,7 & 17,9 & 1,5 & 0,3 \\
\hline NAD & 95664 & 25,7 & 56,0 & 16,8 & 1,2 & 0,3 \\
\hline SAD & 111696 & 25,7 & 60,1 & 12,7 & 0,2 & 1,3 \\
\hline $\begin{array}{l}\text { Significance } \\
\text { in } \\
\text { differences }\end{array}$ & & $\begin{array}{l}* * *(\mathrm{CAD}- \\
\text { NAD) } \\
* * *(\mathrm{CAD}- \\
\text { SAD })\end{array}$ & $\begin{array}{c}* * *(\mathrm{CAD}- \\
\mathrm{NAD}) \\
* * *(\mathrm{CAD}- \\
\mathrm{SAD}) \\
* * *(\mathrm{CAO}-\mathrm{SAD})\end{array}$ & $\begin{array}{c}* * *(\mathrm{CAD}-\mathrm{NAD}) \\
* * *(\mathrm{CAD}-\mathrm{SAD}) \\
* * *(\mathrm{NAD}-\mathrm{SAD})\end{array}$ & & $*(\mathrm{CAD}-\mathrm{SAD})$ \\
\hline
\end{tabular}

Note: $* * *-p \leq 0,001 ; * *-p \leq 0,01 ; *-p \leq 0,05$.

Table 4

Odds ratio for school-related diseases based on the results of preventative medical exams of children in the three Moscow districts with various sanitary levels, 2010

\begin{tabular}{|c|c|c|c|c|c|}
\hline Indicator & \multirow[b]{2}{*}{ Examined } & \multicolumn{2}{|c|}{ Worsening vision } & \multicolumn{2}{|c|}{ Postural disorder } \\
\hline Examined groups & & abs & $\begin{array}{c}\text { per } 100 \\
\text { exams }\end{array}$ & abs & $\begin{array}{c}\text { per } 100 \\
\text { exams }\end{array}$ \\
\hline \multicolumn{6}{|l|}{ Central district } \\
\hline Before pre-school & 3444 & 229 & 6,6 & 145 & 4,2 \\
\hline Before high school graduation at 16-17 & 4124 & 928 & 22,5 & 753 & 18,25 \\
\hline$O R$ (odds ratio) $\pm m$ & & $4,0 \pm 0,52$ & & $5,1 \pm 0,52$ & \\
\hline \multicolumn{6}{|l|}{ Northern district } \\
\hline Before pre-school & 8680 & 471 & 5,4 & 159 & 1,8 \\
\hline Before high school graduation at 16-17 & $6485 \pm 6104$ & 1803 & 27,8 & 796 & 13,0 \\
\hline$O R$ (odds ratio) $\pm m$ & & $6,7 \pm 0,49$ & & $8,0 \pm 0,49$ & \\
\hline Significance of difference CAD -CAO & & $\begin{array}{c}t=3,8 \\
p<0,001\end{array}$ & & $\begin{array}{c}t=4,1 \\
p<0,001\end{array}$ & \\
\hline \multicolumn{6}{|l|}{ Southern district } \\
\hline Before pre-school & 12264 & 775 & 6,3 & 253 & 2,1 \\
\hline Before high school graduation at 16-17 & 8146 & 2479 & 30,4 & 1229 & 15,1 \\
\hline$O R$ (odds ratio) $\pm m$ & & $6,5 \pm 0,54$ & & $8,4 \pm 0,54$ & \\
\hline Significance of difference CAD -ЮAO & & $\begin{array}{c}t=3,3 \\
p<0,001\end{array}$ & & $\begin{array}{c}t=4,4 \\
p<0,001\end{array}$ & \\
\hline
\end{tabular}

The risks associated with school-related health disorders, based on the results of medical examinations, were higher in the Moscow districts characterized by a lower level of sanitary and epidemiological environment at the educational facilities by the number of the facilities of the 2nd sanitary group and the number of students exposed to the sanitary and hygienic environment that does not meet the requirements.

As a result, the management of sanitary and epidemiological environment at the educational institutions calls for more actual approaches that would allow the assessment of the sanitary and hygienic environment at the educational institution and the impact of learning conditions on students' health $[2,3,5,9]$. An action program to improve the organization and implementation of inspection activities aimed at controlling the quality of indoor environment at 
the educational institutions is needed. Educational facilities also need to make sure they follow the sanitary and hygienic requirements. For this purpose they can use government-approved activities as well as innovative methods approved in other areas: operational supervision over the implementation of the sanitary and hygienic regulations and activities with the account for the level of the sanitary and epidemiological well-being of the educational facility; sanitary and epidemiological audit at the educational institutions.

The level of health of the children and teenagers should serve as an indicator of the efficiency of the sanitary service. The data on children's morbidity and the results of medical exams serves as validation for governmental and intergovernmental management decisions to ensure safety of the learning environment, and reduction in health risks.

\section{References}

1. Baranov A.A., Kuchma, L.M. Sostoyanie zdorov'ya sovremennykh detey i rol' medikosotsial'nykh faktorov v ego formirovanii [Health status of children and the role of modern medical and social factors in its development]. Vestnik RAMN, 2009, no. 5, pp. 6-10.

2. Kuchma V.R., Safonkina S.G., Ivanenko A.V. Sanitarno-epidemiologicheskiy audit v obrazovatel'nykh uchrezhdeniyakh: problemy i puti resheniya [Sanitary and epidemiological audit of educational institutions: problems and solutions]. Zdorov'e naseleniya i sreda obitaniya, 2012, no. 6, pp. 11-14.

3. Kuchma V.R., Shubochkina E.I. O novykh nauchnykh podkhodakh k upravleniyu sistemoy sanitarno-epidemiologicheskogo blagopoluchiya obuchayushchikhsya $\mathrm{v}$ obshcheobrazovatel'nykh uchrezhdeniyakh [On the new scientific approaches to the management of sanitary-epidemiological safety of schoolchildren in educational institutions]. Zdorov'e naseleniya i sreda obitaniya, 2013, no. 8, pp. 6-9.

4. Novikova I.I. Gigienicheskaya otsenka zakonomernostey formirovaniya zdorov'ya shkol'nikov krupnogo promyshlennogo tsentra avtoref. diss. dok. med.nauk [Hygienic evaluation of schoolchildren' laws of health formation in a large industrial center]. Omsk, 2006, p. 34.

5. Kuchma V.R., Sukhareva L.M., Stepanova M.I., Aleksandrova I.E., Shumkova T.V. Novye podkhody kgigienicheskoy otsenke usloviy $i$ rezhimov obucheniya $v$ obshcheobrazovatel'nykh uchrezhdeniyakh [New approaches to the assessment of sanitary conditions and modes of learning in educational institutions]. Zdorov'e naseleniya $i$ sreda obitaniya, 2013, no. 8, pp. 4-5.

6. Prikaz Federal'noy sluzhby po nadzoru v sfere zashchity prav potrebiteley i blagopoluchiya cheloveka № 787 ot 05.12.2005 [Order of the Federal Service for Supervision of Consumer Rights Protection and Human Welfare № 787 of 05.12.2005].

7. Onishchenko G.G., Kutsenko G.I., Belyaev E.N., Zaytseva N.V., Shur P.Z. Problemy obespecheniya sanitarno-epidemiologicheskogo blagopoluchiya naseleniya [Problems of the sanitary and epidemiological safety of the population]. Moscow, 2000, part 1, p. 197.

8. Maksimov S.A., Davydova E.A., Zinchuk S.F., Zinchuk V.G. Riski i ikh otsenka v mediko-biologicheskikh issledovaniyakh: metodicheskie rekomendatsii, DOZN KO [Risks and their assessment in biomedical researches]. Kemerovo, 2010. $28 \mathrm{p}$.

9. Safonkina S.G., Moldovanov V.V. Nauchno-metodicheskoe obosnovanie podkhodov $\mathrm{k}$ obespecheniyu sanitarno-epidemiologicheskogo blagopoluchiya $\mathrm{v}$ obrazovatel'nykh uchrezhdeniyakh [Scientific and methodological approaches to the provision of 
sanitary and epidemiological safety in educational institutions]. Zdorov'e naseleniya $i$ sreda obitaniya, 2013, no. 12, pp. 37-39.

10. Shubochkina E.I., Moldavanov V.V, Ibragimova E.M. Otsenka svyazi mezhdu pokazatelyami sostoyaniya zdorov'ya detey i urovnem sanepidblagopoluchiya obrazovatel'nykh uchrezhdeniy» [Assessment of correlation between indicators of children's health and level of sanitary and epidemiologic safety of educational institutions]. M-ly Plenuma NS po ekologii cheloveka $i$ gigiene okruzhayushchey sredy "Nauchno-metodologicheskie $i$ zakonodatel'nye osnovy sovershenstvovaniya normativno-pravovoy bazy profilakticheskogo zdravookhraneniya: problemy i puti resheniya» 13-14 dekabrya 2012. Moscow, 2012, pp. 491-493. 